Article

\title{
Papain-Catalyzed Synthesis of Polyglutamate Containing a Nylon Monomer Unit
}

\author{
Kenjiro Yazawa and Keiji Numata * \\ Enzyme Research Team, RIKEN Center for Sustainable Resource Science, 2-1 Hirosawa, Wakoshi, \\ Saitama 351-0198, Japan; kenjiro.yazawa@riken.jp \\ * Correspondence: keiji.numata@riken.jp; Tel.: +81-48-467-9525; Fax: +81-48-462-4664 \\ Academic Editor: Katja Loos \\ Received: 26 April 2016; Accepted: 11 May 2016; Published: 13 May 2016
}

\begin{abstract}
Peptides have the potential to serve as an alternative for petroleum-based polymers to support a sustainable society. However, they lack thermoplasticity, owing to their strong intermolecular interactions. In contrast, nylon is famous for its thermoplasticity and chemical resistance. Here, we synthesized peptides containing a nylon unit to modify their thermal properties by using papain-catalyzed chemoenzymatic polymerization. We used L-glutamic acid alkyl ester as the amino acid monomer and nylon 1,3,4, and 6 alkyl esters as the nylon unit. Papain catalyzed the copolymerization of glutamic acid with nylon 3, 4, and 6 alkyl esters, whereas the nylon 1 unit could not be copolymerized. Other proteases used in this study, namely, bromelain, proteinase $\mathrm{K}$, and Candida antarctica lipase (CALB), were not able to copolymerize with any nylon units. The broad substrate specificity of papain enabled the copolymerization of L-glutamic acid with a nylon unit. The peptides with nylon units demonstrated different thermal profiles from that of oligo(L-glutamic acid). Therefore, the resultant peptides with various nylon units are expected to form fewer intermolecular hydrogen bonds, thus altering their thermal properties. This finding is expected to broaden the applications of peptide materials and chemoenzymatic polymerization.
\end{abstract}

Keywords: chemoenzymatic synthesis; aminolysis; peptide; papain; bromelain; proteinase K; lipase; thermal property; nylon

\section{Introduction}

Peptides have received attention as eco-friendly alternatives for petroleum-based materials because of their unique physical properties and biological functions. For human use of peptides as bulk materials, it would be expected that peptide-based materials would need to be fabricated via a thermal process without any organic solvents [1]. However, peptides do not have a melting point but instead show decomposition during the heating process because the intermolecular hydrogen bonds in peptides are so strong that the intrachain covalent bonds begin to degrade before the melting transition [2]. To design thermally processable peptide materials, we therefore focus on the copolymerization of peptides and unnatural components. In this study, we selected nylon units as a peptide partner because nylon has an amide bond and has characteristics of thermoplasticity and chemical resistance. In addition, nylon 4 is an attractive unit because of its biomass-based origin and biodegradability in natural environment [3]. Thus, the introduction of nylon units into peptides changes the density of hydrogen bonds between the peptide main chains and can lead to new functions such as peptides with unique thermal properties.

To synthesize peptides, solid phase peptide synthesis requiring protection-deprotection procedures is generally used [4-6]. Peptides can also be biosynthesized by using recombinant DNA expression systems, in which amino acid sequences influence protein yield as well as productivity, and multistep purifications are necessary [7-10]. In this study, we focused on chemoenzymatic peptide 
synthesis to copolymerize amino acid and nylon units. Chemoenzymatic peptide synthesis is a hydrolase-catalyzed polymerization that has the possibility of introducing unnatural amino acids and artificial units [11-14], and it is a clean, mild, stereoselective reaction with a high atom economy [14]. Proteases generally function as hydrolases, and they are also able to catalyze aminolysis. The aminolysis can proceed kinetically when excess substrate amino acids are present around the enzyme. Papain, a cysteine protease, shows broad substrate specificity and exhibits endopeptidase, amidase, and esterase activities, which have been widely used in chemoenzymatic synthesis [15-21]. Beer et al. have provided the first demonstration that papain can recognize the nylon 3 monomer $\beta$-alanine as a substrate in a dipeptide synthesis [16]. Thus, papain is expected to incorporate unnatural amino acids such as nylon monomers. Here, we used papain to synthesize peptides with nylon units. We also used other enzymes, namely bromelain, proteinase K, and Candida antarctica lipase B (CALB). Bromelain is a cysteine protease with broad substrate specificity and is frequently used in chemoenzymatic synthesis [22-26]. Proteinase $\mathrm{K}$ is a serine protease that has affinity not only for the peptide bond next to the carboxyl group of aliphatic amino acids but also for esters [27-29]. CALB is a lipolytic enzyme that catalyzes many reactions, such as esterification, amidation, and transesterification [30-35]. Lipase-catalyzed amide bond formations have been reported by Loos et al. [35] and Cheng et al. [36]. We compared the reaction efficiencies of the four enzymes used in this study.

As a model amino acid monomer, we used L-glutamic acid diethyl ester $\left(\mathrm{Glu}(\mathrm{Et})_{2}\right)$ because of its relatively high reactivity. We selected four types of commercially available nylon monomers-nylon 1 [ethyl carbamate (nylon $1 \mathrm{Et}$ )], nylon 3 [ $\beta$-alanine methyl ester hydrochloride (nylon 3Me), $\beta$-alanine ethyl ester hydrochloride (nylon 3Et)], nylon 4 [methyl 4-aminobutyrate hydrochloride (nylon 4Me), ethyl 4-aminobutyrate hydrochloride (nylon 4Et)], and nylon 6 [methyl 6-aminohexanoate hydrochloride (nylon 6Me)]— to copolymerize with Glu(Et) ${ }_{2}$ (Figure 1). In particular, nylon 4 is biomass-based and biodegradable, and it is considered to be an eco-friendly bioplastic [3]. However, the process window (gap between melting and degradation temperatures) is too small to allow practical industrial processing. Copolymers of the nylon 4 unit and amino acids can be used as an eco-friendly and biomass-based material.

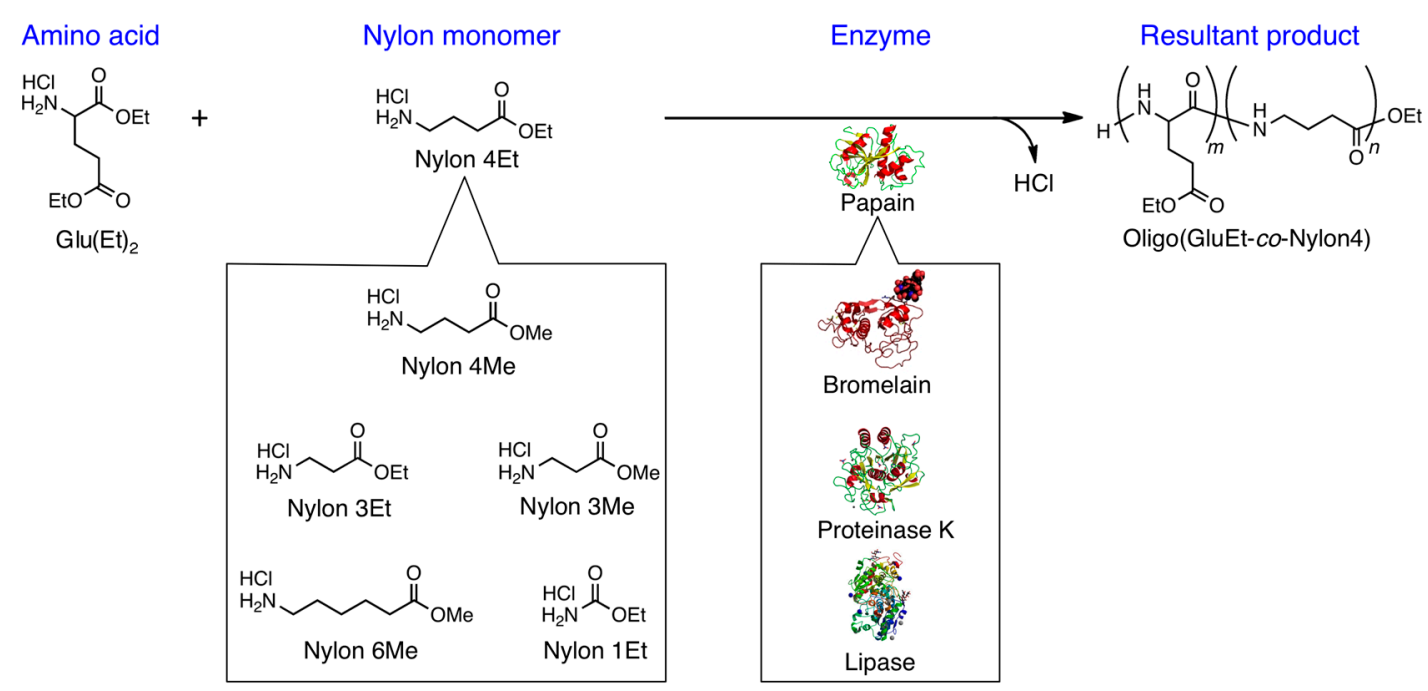

Figure 1. Schematic illustration of the copolymerization of amino acids and nylon monomers by chemoenzymatic synthesis. Glu(Et $)_{2}$ was used as a model amino acid, whereas six types of nylon monomer alkyl esters with various chain lengths were used as the nylon unit. Chemoenzymatic synthesis was performed using four enzymes, and their reaction efficiencies were investigated.

In this study, oligo glutamic acid- $\gamma$-ethyl ester (oligo(GluEt)) with a nylon unit, which was synthesized by chemoenzymatic copolymerization, was characterized by ${ }^{1} \mathrm{H}$ nuclear magnetic 
resonance (NMR) and matrix assisted laser desorption ionization time of flight mass spectrometry (MALDI-TOF MS) to confirm the resultant compositions. The thermal properties of oligo(GluEt) with a nylon unit were also characterized by thermogravimetric analysis (TGA) and differential scanning calorimetry (DSC) to evaluate the effect of the nylon unit on the thermal properties of the peptides. From these results, the relationship between the nylon units and thermal properties was determined, considering the density of hydrogen bonds between the peptide main chains.

\section{Materials and Methods}

\subsection{Materials}

L-Glutamic acid diethyl ester hydrochloride, methyl 4-aminobutyrate hydrochloride (nylon $4 \mathrm{Me}$ ), ethyl 4-aminobutyrate hydrochloride (nylon $4 \mathrm{Et}$ ), $\beta$-alanine methyl ester hydrochloride (nylon $3 \mathrm{Me}$ ), $\beta$-alanine ethyl ester hydrochloride (nylon 3Et), methyl 6-aminohexanoate hydrochloride (nylon 6Me), 2-(4-hydroxyphenylazo) benzoic acid (HABA), sodium trifluoroacetate (Na-TFA), and Candida antarctica lipase B (CALB) were purchased from Sigma-Aldrich (St. Louis, MO, USA). Ethyl carbamate (nylon 1Et), papain, bromelain, and proteinase $\mathrm{K}$ were purchased from Wako Pure Chemical Industries (Osaka, Japan). All of the chemicals and enzymes were used without any purification. The activity of papain was $0.0015 \mathrm{U} / \mathrm{mg}$, and one unit was defined to hydrolyze $N \alpha$-benzoyl-L-arginine- $p$-nitroanilide hydrochloride and release $1 \mu \mathrm{mol}$ of $p$-nitroaniline per minute at a pH of 7.5 and $25^{\circ} \mathrm{C}$. The activity of bromelain was $1090 \mathrm{U} / \mathrm{mg}$, and one unit was defined to hydrolyze $N \alpha$-carbobenzoxy-L-lysine- $p$-nitrophenyl ester and release $1 \mu \mathrm{mol}$ of $p$-nitrophenol per minute at a $\mathrm{pH}$ of 4.6 and $25^{\circ} \mathrm{C}$. The activity of proteinase $\mathrm{K}$ was $23 \mathrm{U} / \mathrm{mg}$, and one unit was defined to hydrolyze urea-denatured hemoglobin and to produce color equivalent to $1 \mu \mathrm{mol}$ of tyrosine per minute at a $\mathrm{pH}$ of 7.5 and $37^{\circ} \mathrm{C}$. The activity of lipase was $819 \mathrm{U} / \mathrm{mg}$, and one unit was defined to hydrolyze triacylglycerol and release $1 \mu \mathrm{mol}$ of fatty acid per hour at a $\mathrm{pH}$ of 7.2 and $37^{\circ} \mathrm{C}$.

\subsection{Chemoenzymatic Peptide Synthesis}

The reaction conditions were slightly modified from those in a previous report on the chemoenzymatic synthesis of oligo(GluEt) catalyzed by papain [17]. Briefly, a molar excess of nylon monomer $(0.54 \mathrm{M})$ and $\mathrm{Glu}(\mathrm{Et})_{2}(0.06 \mathrm{M})$ were mixed with $20 \mathrm{mg} / \mathrm{mL}$ papain, bromelain, proteinase $\mathrm{K}$, or lipase in $5 \mathrm{~mL}$ of $1 \mathrm{M}$ phosphate buffer at a $\mathrm{pH}$ of 8.0. The chemoenzymatic reactions were performed at $40^{\circ} \mathrm{C}$ for $12 \mathrm{~h}$ and stirred at $1000 \mathrm{rpm}$ using an EYELA ChemiStation (Tokyo, Japan). The resultant white precipitate was centrifuged at $12,000 \times g$ for $5 \mathrm{~min}$ and was washed with diluted $\mathrm{HCl}(\mathrm{pH}=2)$ twice and with Milli-Q water. The products were lyophilized.

\subsection{MALDI-TOF MS}

The MALDI-TOF MS spectra were obtained using an Autoflex Speed MALDI-TOF-MS system spectrophotometer (Bruker, Bremen, Germany) operating in linear positive mode. The lyophilized product $(0.4 \mathrm{mg} / \mathrm{mL})$ was dissolved in TA solution, consisting of $0.1 \%$ trifluoroacetic acid, $80 \%$ acetonitrile, and $20 \%$ water. Then, the sample solution was mixed with $20 \mathrm{mg} / \mathrm{mL}$ HABA and $1 \mathrm{mg} / \mathrm{mL} \mathrm{Na-TFA,} \mathrm{which} \mathrm{were} \mathrm{used} \mathrm{as} \mathrm{the} \mathrm{matrix} \mathrm{and} \mathrm{cationic} \mathrm{reagent,} \mathrm{respectively.} \mathrm{The} \mathrm{prepared}$ sample $(1 \mu \mathrm{L})$ was spotted on the target plate and dried at an ambient temperature. The acquired data were analyzed with FLEX analysis software (Bruker, Bremen, Germany).

\section{4. ${ }^{1} H-N M R$}

${ }^{1} \mathrm{H}-\mathrm{NMR}$ was recorded on a Varian NMR System 500 (500 MHz) spectrometer (Varian Medical Systems, Palo Alto, CA, USA) at $25{ }^{\circ} \mathrm{C}$ controlled with VnmrJ software (Agilent Technologies, Santa Clara, CA, USA). The lyophilized samples were dissolved in dimethyl sulfoxide- $d_{6}$ (DMSO- $d_{6}$ ) at a concentration of $10 \mathrm{mg} / \mathrm{mL}$. One hundred and twenty-eight scans were recorded during each 
${ }^{1} \mathrm{H}-\mathrm{NMR}$ measurement. Data were processed and analyzed using ACD/NMR Processor Academic Edition, version 12.01 (Advanced Chemistry Development, Toronto, ON, Canada).

\subsection{Thermal Analysis}

TGA and DSC measurements were performed simultaneously by using a TGA/DSC2 (Mettler Toledo, Greifensee, Switzerland) according to a previous study [37]. The sample synthesized by chemoenzymatic polymerization $(5-7 \mathrm{mg}$ ) was weighed and sealed in an aluminum pan. The lid of the aluminum pan had a pinhole to prevent the pan from bursting because of an increase in the internal pressure during the heating process. The product was heated at $10{ }^{\circ} \mathrm{C} / \mathrm{min}$ from 30 to $400{ }^{\circ} \mathrm{C}$ under a nitrogen atmosphere in triplicate. The device was calibrated with an empty cell to form a baseline and with indium to characterize the heat flow and temperature of the system.

\section{Results and Discussion}

\subsection{Papain-Catalyzed Copolymerization of Peptides with a Nylon 4 Unit}

Methyl and ethyl esters of monomeric substrates were used in this study because of their relatively higher reactivities in comparison to those of the free amino acids and nylon units $[15,28]$. Because the $p K_{\mathrm{a}}$ of substrate monomer is the main determinant of the reaction efficiency in the chemoenzymatic polymerizatrion, yield and degree of polymerization are largely dependent on the $\mathrm{pH}$ of the reaction medium [14]. Therefore, we set the $\mathrm{pH}$ of 8 using phosphate buffer, which is within the range of optimal condition for the chemoenzymatic synthesis by papain [17], bromelain [38], proteinase K [27], and lipase [39]. Furthermore, we set at $40{ }^{\circ} \mathrm{C}$ for the aminolysis reaction, because the aminolysis activity was larger at $40^{\circ} \mathrm{C}$ in the polymerization by papain [17], bromelain [38], and proteinase $\mathrm{K}$ [27]. In addition, we found that the substrate monomer, namely L-glutamic acid diethyl ester, tends to be hydrolyzed when the reaction temperature was set over $40^{\circ} \mathrm{C}$ [29]. Therefore, we used $\mathrm{pH} 8$ and $40{ }^{\circ} \mathrm{C}$ for the reaction conditions. As the first step, we performed papain-catalyzed chemoenzymatic synthesis using $\mathrm{Glu}(\mathrm{Et})_{2}$ and nylon $4 \mathrm{Et}$ and then obtained a resultant white precipitate at a yield of $53 \%$ based on the initial amounts of the monomers used in the reaction. The MALDI-TOF MS spectrum of the resultant product is shown in Figure 2a. Peaks with constant intervals of $157 \mathrm{~g} / \mathrm{mol}$ were detected, thus indicating that oligo(GluEt) was successfully synthesized with DP from 7 to 12 . In this study, the limiting factor of polymer length is mainly determined by the solubility of the resultant product in the reaction medium. When peptide chains elongate to a length at which they are insoluble, they precipitate from solution, which prevents the increase of the molecular weight. In addition, the other peaks with an interval of $85 \mathrm{~g} / \mathrm{mol}$ apart from the peaks derived from oligo(GluEt) indicated that oligo(GluEt) and only one nylon 4 unit were copolymerized. We did not detect any peaks derived from peptides containing more than two nylon 4 units. The resultant product was also characterized by ${ }^{1} \mathrm{H}-\mathrm{NMR}$ (Figure 2b), and nylon-derived peaks were detected in addition to the peaks assigned to oligo(GluEt). From the ${ }^{1} \mathrm{H}-\mathrm{NMR}$ results, approximately 1 out of $10 \mathrm{oligo}(\mathrm{GluEt})$ had a nylon $4 \mathrm{Et}$ unit, according to the integral values of the peaks corresponding to the $\mathrm{N}$-terminal $\alpha$-proton and C-terminal methylene proton shown as $\mathrm{D}^{\prime}$ and $\mathrm{G}$, respectively, in Figure $2 \mathrm{~b}$. The formation of $\gamma$-glutamate linkage in the oligomer was not detected, based on the ${ }^{1} \mathrm{H}-\mathrm{NMR}$ of the resultant product and a previous report on poly ( $\alpha$-methyl $\gamma$-L-glutamate) [40]. Furthermore, the oligomers formed from diethyl L-glutamate hydrochloride using papain were exclusively $\alpha$-linked, which was confirmed by ${ }^{1} \mathrm{H}-{ }^{1} \mathrm{H}$ COSY NMR [41]. In addition, the papain-catalyzed polymerization of $\gamma$-methyl L-glutamate resulted in no occurrence of the polymerization [41]. These data indicate that the poly- $\alpha$-glutamate was exclusively produced in the papain-catalyzed synthesis. The MALDI-TOF MS spectra showed a negligible amount of free pendant carboxylic acid in the resultant product. The major series of signals were derived from the product with ester groups. According to the ${ }^{1} \mathrm{H}-\mathrm{NMR}$ spectra, the ratio of the integration value between the peaks derived from the $\mathrm{N}$-terminal $\alpha$-proton and the C-terminal ester group was nearly identical, which indicates that almost all the ester groups maintained. Thus, 
our resultant product was mainly composed of the ester moiety at the C-terminus. This is probably because the resultant product was formed as precipitate, which limits accessibility of papain to the resultant product and prevents the hydrolysis of the ester bonds.
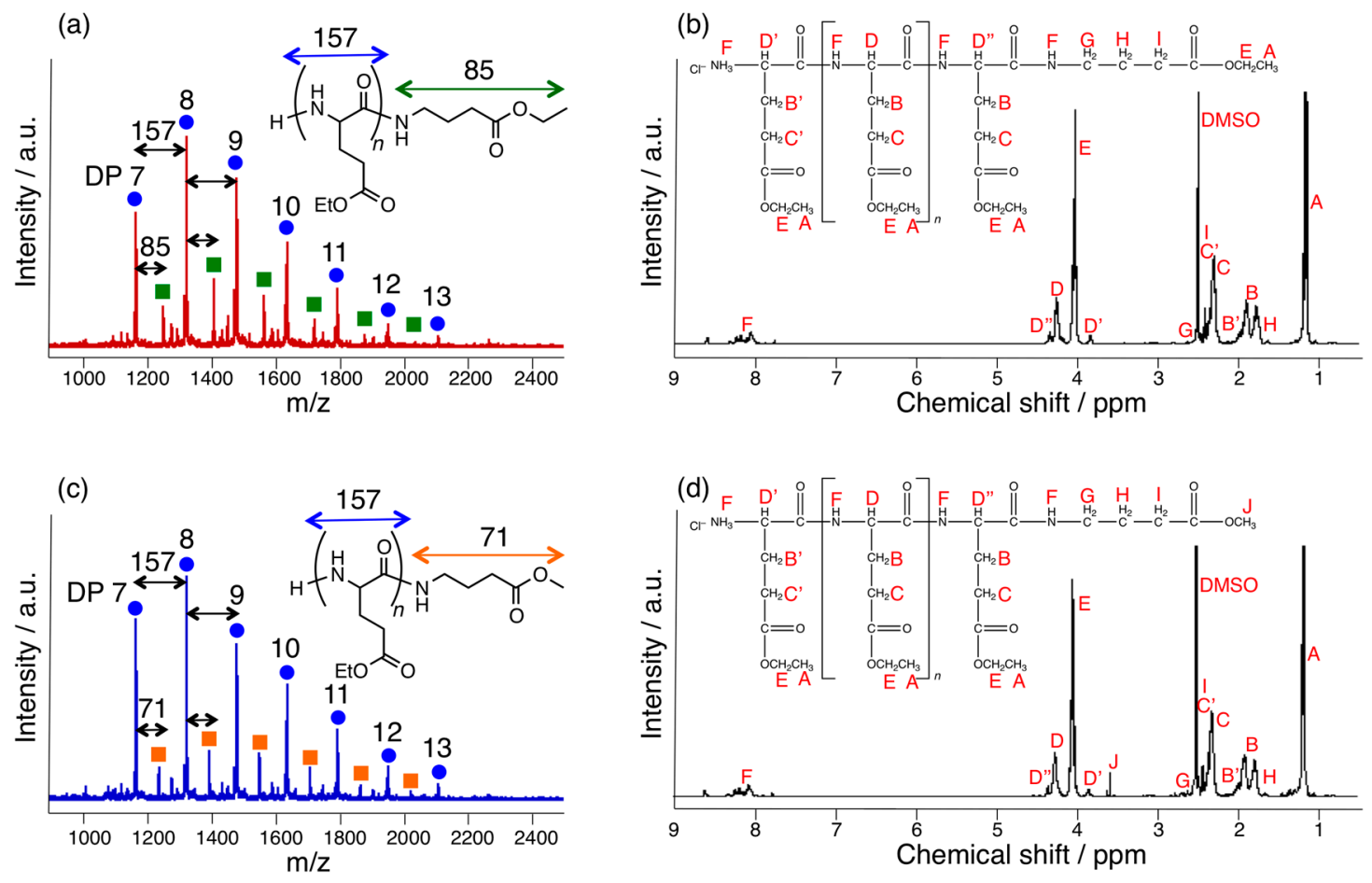

Figure 2. MALDI-TOF MS (a,c) and ${ }^{1} \mathrm{H}-\mathrm{NMR}(\mathbf{b}, \mathbf{d})$ spectra of the papain-catalyzed reaction product using $\mathrm{Glu}(\mathrm{Et})_{2}$ with nylon $4 \mathrm{Et}(\mathbf{a}, \mathbf{b})$ or nylon $4 \mathrm{Me}(\mathbf{c}, \mathbf{d})$ as substrates. Mass spectra were obtained in the linear positive mode using HABA and Na-TFA as the matrix and cationic reagent, respectively. Peaks with blue circles denote oligo(GluEt) with various DP, whereas peaks with green (a) or orange (c) squares denote oligo(GluEt) with a nylon $4 \mathrm{Et}$ or nylon $4 \mathrm{Me}$, respectively. DMSO- $d_{6}$ was used as the solvent in NMR measurements.

To clarify the difference between nylon ethyl ester and nylon methyl ester, we additionally used nylon $4 \mathrm{Me}$ as a nylon unit, which resulted in a reaction yield of $45 \%$. The MALDI-TOF MS spectrum of the peptide from $\mathrm{Glu}(\mathrm{Et})_{2}$ and nylon 4 Me showed peaks with constant intervals of $157 \mathrm{~g} / \mathrm{mol}$ derived from oligo(GluEt) with DP from 7 to 12 in Figure 2c. Peaks with an interval of $71 \mathrm{~g} / \mathrm{mol}$ apart from the peaks derived from the oligo(GluEt) were also detected, thus confirming that the nylon 4 unit was introduced into the peptide. The ${ }^{1} \mathrm{H}-\mathrm{NMR}$ spectrum indicated that approximately 1 out of 10 oligo(GluEt) contained a nylon 4 unit (Figure 2d). The comparison between the reactions using nylon 4Et and nylon 4Me demonstrated that the differences in MS peak intervals were $85 \mathrm{~g} / \mathrm{mol}$ and $71 \mathrm{~g} / \mathrm{mol}$ apart from the peaks of oligo(GluEt) for nylon $4 \mathrm{Et}$ and nylon $4 \mathrm{Me}$, respectively. If the nylon 4 unit were introduced at the N-terminus or the inner part of the resultant peptide, the molecular weight difference between the resultant products using nylon 4Et and nylon 4Me would be the same. Thus, we concluded that the nylon 4 unit was introduced at the C-terminus of oligo(GluEt). In the papain-catalyzed chemoenzymatic synthesis, the catalytic cysteine residue of papain forms a covalent bond with the carboxyl ester group of the monomer, thus resulting in formation of the enzyme-substrate (ES) complex (Scheme 1) [21]. The nucleophilic attack by the amine group of monomers allows peptide bond formation by aminolysis. It has been demonstrated that recognition of $\mathrm{D}$-alanine and $\beta$-alanine by papain is approximately 100 times lower than that of L-alanine [16]. Although our reaction system contained nine times more nylon monomers than amino acids, introducing the nylon unit into the peptide was still difficult. Therefore, the nylon 4 unit was introduced only at the C-terminus. The 
results of this study and previous reports suggest that ES complex formation of the nylon 4 unit at the C-terminus with papain is not efficient enough to continue the polymerization (Scheme 1).

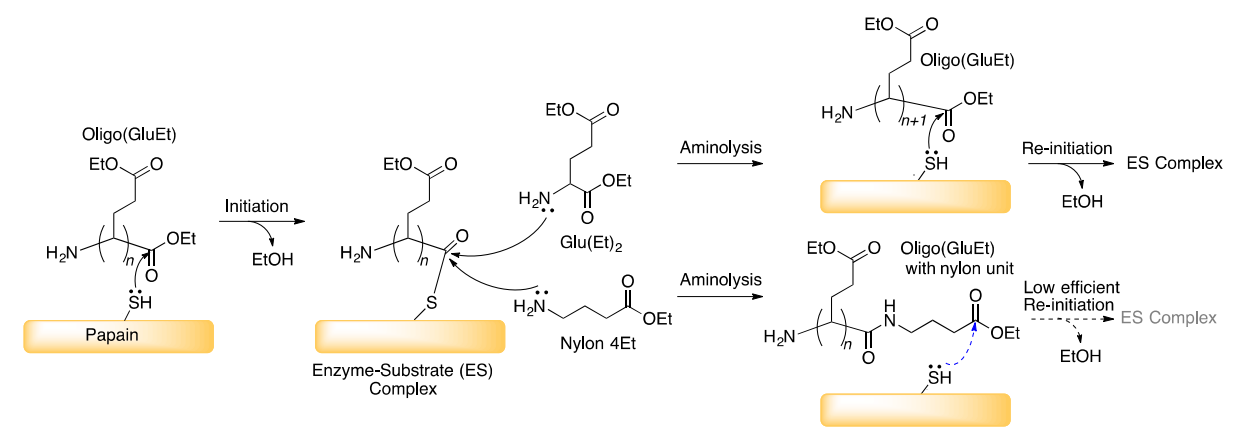

Scheme 1. Reaction scheme of the papain-catalyzed synthesis of peptides with a nylon unit.

\subsection{Bromelain, Proteinase K, and Lipase-Catalyzed Chemoenzymatic Synthesis Using Glu(Et) $)_{2}$ and Nylon $4 E t$}

To evaluate the possibility of using other enzymes to polymerize a nylon into peptides, we performed chemoenzymatic synthesis using the other enzymes, namely, bromelain, proteinase $K$, and lipase (CALB). We found that bromelain catalyzed the oligomerization of $\mathrm{Glu}(\mathrm{Et})_{2}$, but the nylon 4 unit was not introduced into the peptide according to MALDI-TOF MS and ${ }^{1} \mathrm{H}-\mathrm{NMR}$ spectra (Figure 3a,b). Bromelain is a cysteine protease like papain. Although the catalytic residues are identical in bromelain and papain, we reasoned that the difference in the binding sites for the substrates between bromelain and papain might affect the introduction of nylon 4 unit.
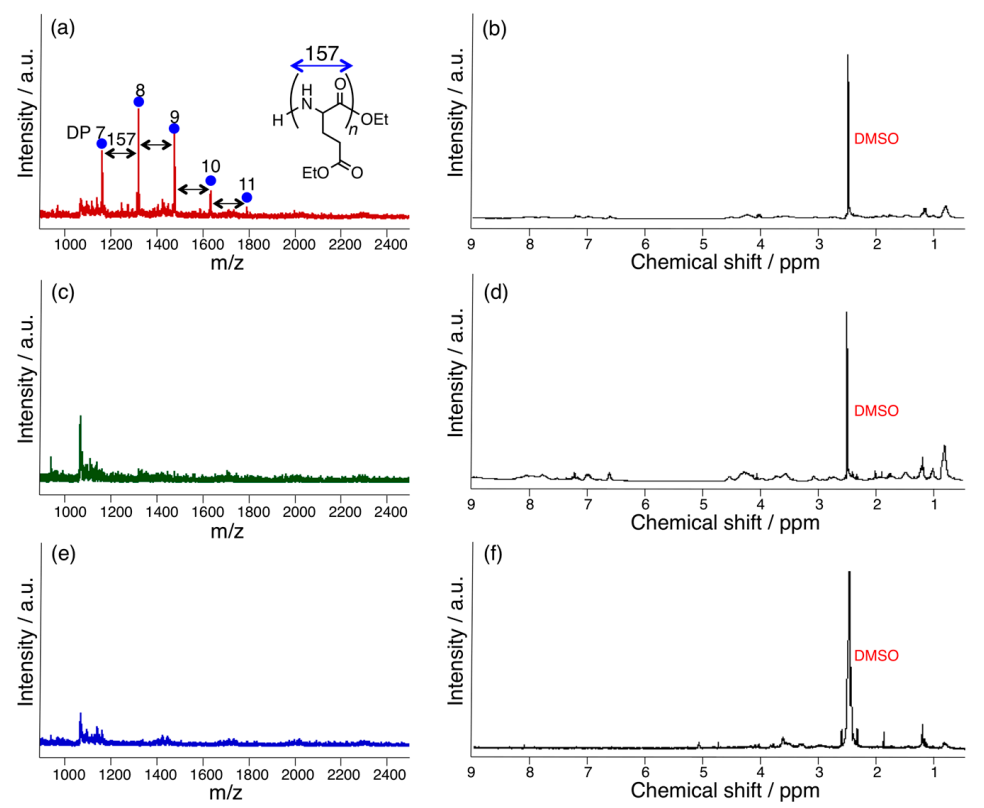

Figure 3. MALDI-TOF MS (a,c,e) and ${ }^{1} \mathrm{H}-\mathrm{NMR}(\mathbf{b}, \mathbf{d}, \mathbf{f})$ spectra of bromelain $(\mathbf{a}, \mathbf{b})$, proteinase $\mathrm{K}(\mathbf{c}, \mathbf{d})$, and lipase $(\mathbf{e}, \mathbf{f})$-catalyzed product using $\mathrm{Glu}(\mathrm{Et})_{2}$ and nylon $4 \mathrm{Et}$ as substrates. Mass spectra were obtained in linear positive mode using HABA and Na-TFA as the matrix and cationic reagent, respectively. Peaks with blue circles denote oligo(Glu) with various DP. DMSO- $d_{6}$ was used as the solvent in NMR measurements.

Proteinase K and lipase did not catalyze the oligomerization of glutamic acid or nylon introduction, according to MALDI-TOF MS (Figure 3c,e) and NMR spectra (Figure 3d,f). In the case of proteinase K, not only the catalytic triad Asp39-His69-Ser224 but also the stable substrate recognition site formed 
by Ca ions with Asp200, Val177, and Pro175 is required for the catalytic reactions [42]. In the case of lipase, the active center has a catalytic triad of Ser105-His224-Asp187 containing a large hydrophobic pocket above the catalytic triad and a medium-sized pocket below the catalytic triad [32]. It is assumed that the acyl moiety of the substrate lies in the large pocket, whereas the leaving group moiety lies in the medium pocket in the catalytic pathway [32]. In this study, $\mathrm{Glu}(\mathrm{Et})_{2}$ and nylon monomers were considered unable to meet the requirements for the catalytic pathways of proteinase $\mathrm{K}$ and lipase.

Papain has been reported to recognize $\beta$-alanine as a substrate in dipeptide synthesis [16]. It has been shown in a molecular modeling study that the extra carbon atom in $\beta$-alanine, compared with the natural amino acid, disrupts the hydrogen bonding network with Trp177 in papain, thus resulting in unstable recognition of $\beta$-alanine. The papain-catalyzed recognition rate of $\beta$-alanine has been estimated to be approximately 100 times lower than that of L-alanine [16]. In this study, we added nine-fold greater molar equivalents of nylon monomer than amino acid substrate in the chemoenzymatic reaction, and $13 \mathrm{~mol} \%$ of the nylon unit was introduced into peptide by using papain. According to the resultant nylon composition and monomer feeding ratios, the papain-catalyzed recognition rate of the nylon 4 unit was also estimated to be approximately 100 times lower than that of $\mathrm{Glu}(\mathrm{Et})_{2}$.

\subsection{Papain-Catalyzed Synthesis of Peptides with Nylon 1, 3, or 6 Monomers}

The papain-catalyzed substrate recognition using various nylon monomers, namely, nylon 1Et, nylon $3 \mathrm{Me}$, nylon $3 \mathrm{Et}$, and nylon $6 \mathrm{Me}$, was studied by copolymerization with $\mathrm{Glu}(\mathrm{Et})_{2}$. In the cases of nylon $3 \mathrm{Me}$ and nylon 3Et, papain recognized and catalyzed nylon 3Et and nylon 3Me, and the nylon 3 unit was introduced into the C-terminus of the oligo(GluEt) according to the peaks with constant intervals of 71 and $57 \mathrm{~g} / \mathrm{mol}$ apart from the peaks derived from the oligo(GluEt) in the MALDI-TOF MS spectra (Figure $4 \mathrm{a}, \mathrm{c}$ ). The yields were $49 \% \pm 5 \%$ and $45 \% \pm 2 \%$ when nylon $3 \mathrm{Et}$ and nylon $3 \mathrm{Me}$ were used as substrates, respectively. We did not find any peaks derived from peptides containing more than two nylon 3 units. The NMR spectra in Figure $4 \mathrm{~b}, \mathrm{~d}$ indicated that the nylon compositions were $18 \pm 4 \mathrm{~mol} \%$ and $15 \pm 6 \mathrm{~mol} \%$ for nylon 3Et and nylon 3Me, respectively.
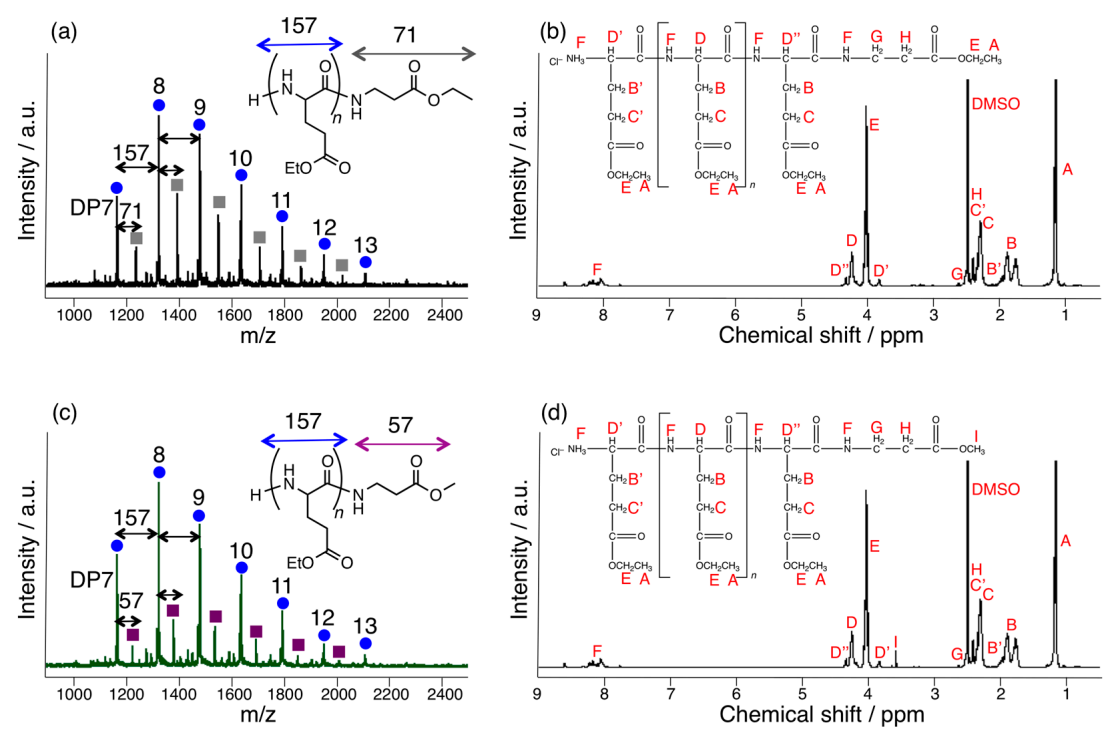

Figure 4. MALDI-TOF MS (a,c) and ${ }^{1} \mathrm{H}-\mathrm{NMR}(\mathbf{c}, \mathbf{d})$ spectra of the papain-catalyzed reaction products using $\mathrm{Glu}(\mathrm{Et})_{2}$ with nylon $3 \mathrm{Et}(\mathbf{a}, \mathbf{b})$ or nylon $3 \mathrm{Me}(\mathbf{c}, \mathbf{d})$ as substrates. Mass spectra were obtained in linear positive mode using HABA and Na-TFA as the matrix and cationic reagent, respectively. Peaks with blue circles denote oligo(GluEt) with various DP, whereas peaks with gray (a) or purple (c) squares denote oligo(GluEt) with nylon $3 \mathrm{Et}$ or nylon $3 \mathrm{Me}$, respectively. DMSO- $d_{6}$ was used as the solvent in NMR measurements. 
Nylon 6Me was also investigated as a substrate of papain. Papain catalyzed the introduction of nylon 6 Me with a yield of $35 \% \pm 3 \%$. Based on the MALDI-TOF MS spectrum shown in Figure $5 \mathrm{a}$, nylon $6 \mathrm{Me}$ was introduced onto the $\mathrm{C}$-terminus of oligo(GluEt). There were no peaks with more than two nylon 6 units. The NMR spectrum in Figure 5b shows that the monomeric composition of nylon 6 was $12 \pm 2 \mathrm{~mol} \%$ by using nylon $6 \mathrm{Me}$ and papain as the monomer and catalyst, respectively.
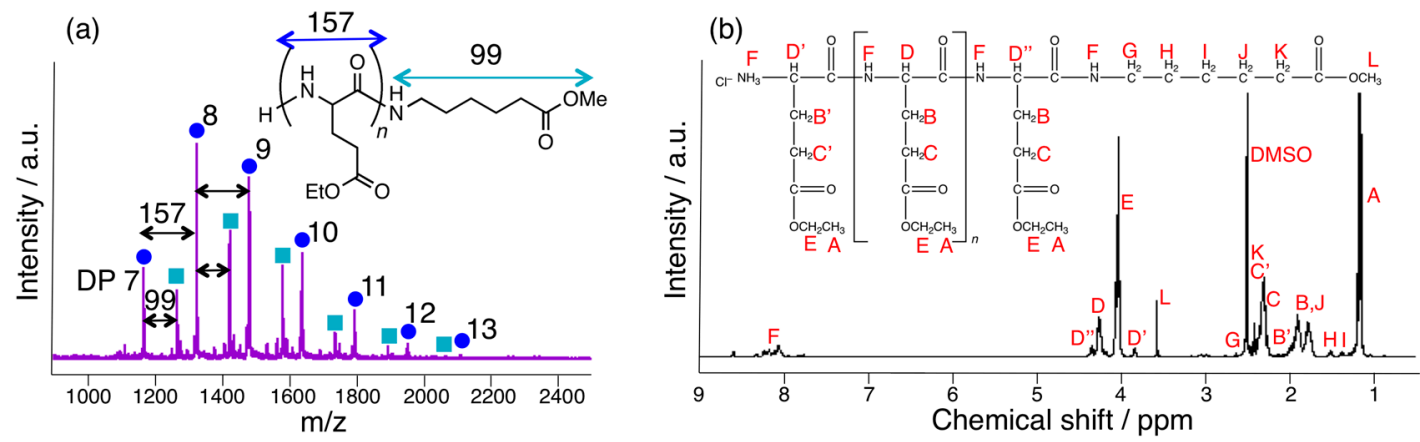

Figure 5. MALDI-TOF MS (a) and ${ }^{1} \mathrm{H}-\mathrm{NMR}(\mathbf{b})$ spectra of the papain-catalyzed reaction product using $\mathrm{Glu}(\mathrm{Et})_{2}$ with nylon $6 \mathrm{Me}$ as substrates. The mass spectrum was obtained in linear positive mode using HABA and Na-TFA as the matrix and cationic reagent, respectively. Peaks with blue circles denote oligo(GluEt) with various DP, and peaks with turquoise squares denote oligo(GluEt) with a nylon 6Me. DMSO- $d_{6}$ was used as the solvent in NMR measurements.

We performed papain-catalyzed synthesis using Glu(Et) ${ }_{2}$ and nylon 1Et. However, papain did not recognize nylon 1Et and synthesized oligo(GluEt) without nylon units in a yield of $40 \% \pm 4 \%$, according to the results by MALDI-TOF MS and ${ }^{1} \mathrm{H}-\mathrm{NMR}$ (Figure $6 \mathrm{a}, \mathrm{b}$ ). This finding was probably because nylon 1Et formed hydrogen bonds poorly with Asp158, Gly66, and Trp177, which is required for substrate affinity in papain [43]. In addition, ethyl carbamate that was used as nylon 1 in this study is estimated to have $p K a$ of -1 [44] and less basic than primary amines. Therefore, the ethyl carbamate was probably difficult to react with catalytic cysteine residue of papain due to its low intrinsic nucleophilicity, thus being unable to form enzyme-substrate complex.

(a)

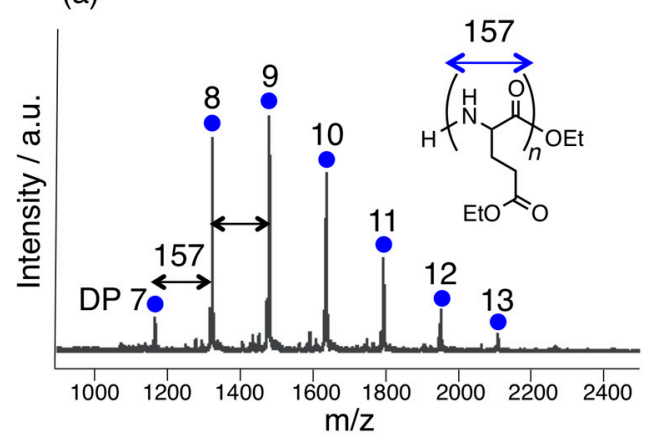

(b)

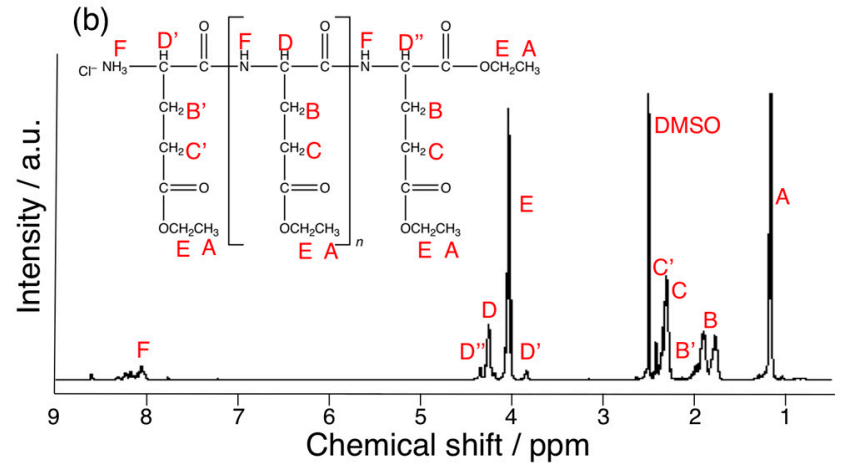

Figure 6. MALDI-TOF MS (a) and ${ }^{1} \mathrm{H}-\mathrm{NMR}(\mathbf{b})$ spectra of the papain-catalyzed reaction product using $\mathrm{Glu}(\mathrm{Et})_{2}$ and nylon 1Et as substrates. The MS spectrum was obtained in linear positive mode using HABA and Na-TFA as the matrix and cationic reagent, respectively. ${ }^{1} \mathrm{H}-\mathrm{NMR}$ was measured using DMSO- $d_{6}$ as the solvent.

Based on the monomeric compositions, Table 1 lists the monomeric composition ratios of nylon units. The chain length and even-odd effects were not significant in the recognition efficiency of papain. The papain-catalyzed recognition rates of the nylon units were similar to that of nylon 4 and 
approximately 100 times lower than that of $\mathrm{Glu}(\mathrm{Et})_{2}$. To evaluate the recognition rate of nylon units in further detail, a more efficient copolymerization system for nylon and amino acids must be developed.

Table 1. Reaction yields and monomeric compositions of the nylon units in the papain-catalyzed synthesis with Glu(Et $)_{2}(n=3)$.

\begin{tabular}{ccc}
\hline Nylon unit & Yield/mol \% & Monomeric composition of nylon unit $/ \mathbf{m o l} \%$ \\
\hline Nylon 4Et & $53 \pm 2$ & $13 \pm 6$ \\
Nylon 4Me & $45 \pm 4$ & $12 \pm 3$ \\
Nylon 3Et & $49 \pm 5$ & $18 \pm 4$ \\
Nylon 3Me & $45 \pm 2$ & $15 \pm 6$ \\
Nylon 6Me & $35 \pm 3$ & $12 \pm 2$ \\
Nylon 1Et & $40 \pm 4$ & Not detected \\
\hline
\end{tabular}

\subsection{Thermal Analysis of oligo(GluEt) with or without Nylon Units}

To evaluate the effects of the nylon units on the thermal properties of oligo(GluEt), we performed TGA and DSC analyses of the resultant oligo(GluEt) with or without nylon units as shown in Figure 7a. On the basis of the DSC profiles, oligo(GluEt) with or without nylon units showed neither a transition temperature nor a melting temperature but demonstrated an endothermic degradation peak ranging from 230 to $350{ }^{\circ} \mathrm{C}$ (Figure 7a). The DSC profile of oligo(GluEt) slightly differed from those of the oligo(GluEt) containing nylon units: the degradation peaks of oligo(GluEt-co-15 mol \% nylon 3Me), oligo(GluEt-co-12 mol \% nylon 4Me) and oligo(GluEt-co-12 mol \% nylon 6Me) shifted to higher temperatures in comparison with the profile of oligo(GluEt). On the basis of the weight loss in the TGA data (Figure $7 b$ ), the degradation temperatures were determined at 1, 5, and $10 \mathrm{wt} \%$ (Table 2). As a result, the oligo(GluEt) with nylon units demonstrated relatively lower thermal stability than oligo (GluEt) did. This result was probably because the intermolecular hydrogen bonds in the oligo(GluEt) with approximately $10 \mathrm{~mol} \%$ of nylon units are prevented by the presence of the nylon units, and thus, the thermal stability of the oligo(GluEt) with nylon units decreased.

(a)

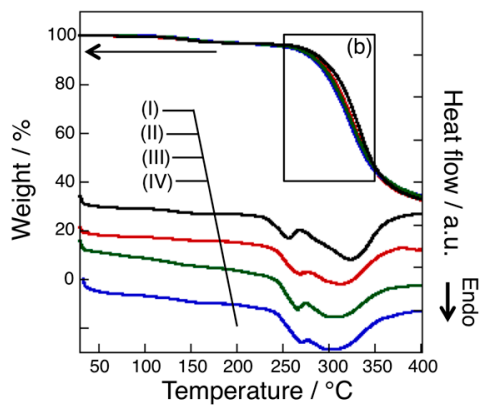

(b)

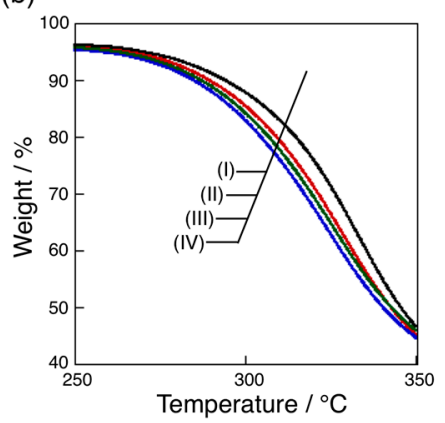

Figure 7. Thermal profiles of (I) oligo(GluEt); (II) oligo(GluEt-co-15 mol \% nylon 3Me); (III) oligo(GluEt-co-12 mol \% nylon 6Me); and (IV) oligo(GluEt-co-12 mol \% nylon 4Me). (a) TGA and DSC from 30 to $400{ }^{\circ} \mathrm{C}$ at $20^{\circ} \mathrm{C} / \mathrm{min}$; (b) Magnified TGA plot in the temperature range from 250 to $350{ }^{\circ} \mathrm{C}$ in (a).

Table 2. Degradation temperature at 1, 5, and $10 \mathrm{wt} \%$ weight loss of oligo(GluEt-co-15 mol \% nylon $3 \mathrm{Me}$ ), oligo(GluEt-co-12 mol \% nylon $4 \mathrm{Me}$ ), and oligo(GluEt-co-12 mol \% nylon $6 \mathrm{Me})(n=3)$.

\begin{tabular}{cccc}
\hline Product & $\mathbf{1 \%}$ Weight loss $/{ }^{\circ} \mathbf{C}$ & $\mathbf{5 \%}$ Weight loss $/{ }^{\circ} \mathbf{C}$ & $\mathbf{1 0 \%}$ Weight loss $/{ }^{\circ} \mathbf{C}$ \\
\hline Oligo(GluEt-co-15 mol \% nylon 3Me) & $130 \pm 6$ & $265 \pm 3$ & $289 \pm 1$ \\
Oligo(GluEt-co-12 mol \% nylon 4Me) & $145 \pm 7$ & $267 \pm 9$ & $289 \pm 4$ \\
Oligo(GluEt-co-12 mol \% nylon 6Me) & $135 \pm 7$ & $267 \pm 6$ & $289 \pm 4$ \\
Oligo(GluEt) & $134 \pm 6$ & $271 \pm 2$ & $295 \pm 1$ \\
\hline
\end{tabular}




\section{Conclusions}

In this study, we successfully introduced nylon 3, 4, and 6 units into the main chains of peptides through papain-catalyzed chemoenzymatic synthesis. The resultant copolymers demonstrated different thermal properties; thus, this study provides a first step toward controlling the thermal properties as well as adding a transition temperature of peptide-based polymers. The peptides containing nylon units are expected to have new functions, such as thermoplasticity, depending on controlling the density of the intermolecular hydrogen bonds. Thus, the papain-catalyzed introduction of nylon monomer into peptide reported in this study may be used more widely not only in peptide synthesis but also in material design in industrial application of peptides and poly(amino acid).

The nylon units were introduced at the C-termini in the resultant peptides because of the lower affinity of the nylon monomers with papain compared with natural amino acids such as glutamic acid. Generally, C-terminal modification is more challenging in comparison with protein N-terminal modification because side chains of aspartic and glutamic acid are as reactive as the general carboxylic acids in the amino acids. Therefore, this chemoenzymatic reaction could be a powerful tool in protein terminal modification, which is crucial in proteomics research.

Acknowledgments: The authors thank the Impulsing Paradigm Change through Disruptive Technologies Program (ImPACT) (Keiji Numata) for financial support of this work.

Author Contributions: Keiji Numata conceived and designed the experiments; Kenjiro Yazawa designed and performed the experiments and analyzed the data; Kenjiro Yazawa and Keiji Numata wrote the paper.

Conflicts of Interest: The authors declare no conflict of interests.

\section{Abbreviations}

The following abbreviations are used in this manuscript:

NMR
MALDI-TOF MS
nylon 4Me
nylon 4Et
nylon 3Me
nylon 3Et
nylon 6Me
nylon 1Et
glu(Et)
oligo(GluEt)
DP
HABA
Na-TFA
DMSO-d6

\section{References}

1. Numata, K. Poly(amino acid)s/polypeptides as potential functional and structural materials. Polym. J. 2015, 47, 537-545. [CrossRef]

2. Cebe, P.; Hu, X.; Kaplan, D.L.; Zhuravlev, E.; Wurm, A.; Arbeiter, D.; Schick, C. Beating the heat-fast scanning melts silk $\beta$ sheet crystals. Sci. Rep. 2013, 3, 1130. [CrossRef] [PubMed]

3. Tachibana, K.; Urano, Y.; Numata, K. Biodegradability of nylon 4 film in a marine environment. Polym. Degrad. Stab. 2013, 98, 1847-1851. [CrossRef]

4. Merrifield, R.B. Solid-phase peptide synthesis. 3. An improved synthesis of bradykinin. Biochemistry 1964, 3, 1385-1390. [CrossRef] [PubMed]

5. Arlinghaus, R.; Shaefer, J.; Schweet, R. Mechanism of peptide bond formation in polypeptide synthesis. Proc. Natl. Acad. Sci. USA 1964, 51, 1291-1299. [CrossRef] [PubMed]

6. Chang, C.-D.; Meienhofer, J. Solid-phase peptide synthesis using mild base cleavage of Nofluorenylmethyloxycarbonylamino acids, exemplified by a synthesis of dihydrosomatostatin. Int. J. Pept. Protein Res. 1978, 11, 246-249. [CrossRef] [PubMed] 
7. Arcidiacono, S.; Mello, C.; Kaplan, D.; Cheley, S.; Bayley, H. Purification and characterization of recombinant spider silk expressed in Escherichia coli. Appl. Microbiol. Biotechnol. 1998, 49, 31-38. [CrossRef] [PubMed]

8. Prince, J.T.; McGrath, K.P.; DiGirolamo, C.M.; Kaplan, D.L. Construction, cloning, and expression of synthetic genes encoding spider dragline silk. Biochemistry 1995, 34, 10879-10885. [CrossRef] [PubMed]

9. Winkler, S.; Szela, S.; Avtges, P.; Valluzzi, R.; Kirschner, D.A.; Kaplan, D. Designing recombinant spider silk proteins to control assembly. Int. J. Biol. Macromol. 1999, 24, 265-270. [CrossRef]

10. Rising, A.; Widhe, M.; Johansson, J.; Hedhammar, M. Spider silk proteins: Recent advances in recombinant production, structure-function relationships and biomedical applications. Cell. Mol. Life Sci. 2011, 68, 169-184. [CrossRef] [PubMed]

11. Ageitos, J.M.; Chuah, J.-A.; Numata, K. Chemo-enzymatic synthesis of linear and branched cationic peptides: Evaluation as gene carriers. Macromol. Biosci. 2015, 15, 990-1003. [CrossRef] [PubMed]

12. Tsuchiya, K.; Numata, K. Papain-catalyzed chemoenzymatic synthesis of telechelic polypeptides using bis(leucine ethyl ester) initiator. Macromol. Biosci. 2016. [CrossRef] [PubMed]

13. Van Rantwijk, F.; Hacking, J.M.A.P.; Sheldon, A.R. Lipase-catalyzed synthesis of carboxylic amides: Nitrogen nucleophiles as acyl acceptor. Monatsh. Chem. 2000, 131, 549-569. [CrossRef]

14. Yazawa, K.; Numata, K. Recent advances in chemoenzymatic peptide syntheses. Molecules 2014, 19, 13755-13774. [CrossRef] [PubMed]

15. Baker, P.J.; Numata, K. Chemoenzymatic synthesis of poly(L-alanine) in aqueous environment. Biomacromolecules 2012, 13, 947-951. [CrossRef] [PubMed]

16. De Beer, R.J.; Zarzycka, B.; Amatdjais-Groenen, H.I.; Jans, S.C.; Nuijens, T.; Quaedflieg, P.J.; van Delft, F.L.; Nabuurs, S.B.; Rutjes, F.P. Papain-catalyzed peptide bond formation: Enzyme-specific activation with guanidinophenyl esters. ChemBioChem 2011, 12, 2201-2207. [CrossRef] [PubMed]

17. Li, G.; Vaidya, A.; Viswanathan, K.; Cui, J.; Xie, W.; Gao, W.; Gross, R.A. Rapid regioselective oligomerization of L-glutamic acid diethyl ester catalyzed by papain. Macromolecules 2006, 39, 7915-7921. [CrossRef]

18. Schwab, L.W.; Kloosterman, W.M.J.; Konieczny, J.; Loos, K. Papain catalyzed (co)oligomerization of $\alpha$-amino acids. Polymers 2012, 4, 710-740. [CrossRef]

19. Fagerland, J.; Finne-Wistrand, A.; Numata, K. Short one-pot chemo-enzymatic synthesis of L-lysine and L-alanine diblock co-oligopeptides. Biomacromolecules 2014, 15, 735-743. [CrossRef] [PubMed]

20. Numata, K.; Baker, P.J. Synthesis of adhesive peptides similar to those found in blue mussel (mytilus edulis) using papain and tyrosinase. Biomacromolecules 2014, 15, 3206-3212. [CrossRef] [PubMed]

21. Ageitos, J.M.; Yazawa, K.; Tateishi, A.; Tsuchiya, K.; Numata, K. The benzyl ester group of amino acid monomers enhances substrate affinity and broadens the substrate specificity of the enzyme catalyst in chemoenzymatic copolymerization. Biomacromolecules 2016, 17, 314-323. [CrossRef] [PubMed]

22. Qin, X.; Xie, W.; Su, Q.; Du, W.; Gross, R.A. Protease-catalyzed oligomerization of L-lysine ethyl ester in aqueous solution. ACS Catal. 2011, 1, 1022-1034. [CrossRef]

23. Qin, X.; Xie, W.; Tian, S.; Ali, M.A.; Shirke, A.; Gross, R.A. Influence of Ne-protecting groups on the protease-catalyzed oligomerization of L-lysine methyl ester. ACS Catal. 2014, 4, 1783-1792. [CrossRef]

24. Viswanathan, K.; Li, G.; Gross, R.A. Protease catalyzed in situ C-terminal modification of oligoglutamate. Macromolecules 2010, 43, 5245-5255. [CrossRef]

25. Viswanathan, K.; Schofield, M.H.; Teraoka, I.; Gross, R.A. Surprising metal binding properties of phytochelatin-like peptides prepared by protease-catalysis. Green Chem. 2012, 14, 1020. [CrossRef]

26. Baker, P.J.; Patwardhan, S.V.; Numata, K. Synthesis of homopolypeptides by aminolysis mediated by proteases encapsulated in silica nanospheres. Macromol. Biosci. 2014, 14, 1619-1626. [CrossRef] [PubMed]

27. Ageitos, J.M.; Baker, P.J.; Sugahara, M.; Numata, K. Proteinase K-catalyzed synthesis of linear and star oligo(L-phenylalanine) conjugates. Biomacromolecules 2013, 14, 3635-3642. [CrossRef] [PubMed]

28. Ma, Y.; Sato, R.; Li, Z.; Numata, K. Chemoenzymatic synthesis of oligo(L-cysteine) for use as a thermostable bio-based material. Macromol. Biosci. 2016, 16, 151-159. [CrossRef] [PubMed]

29. Yazawa, K.; Sugahara, M.; Yutani, K.; Takehira, M.; Numata, K. Derivatization of proteinase K with heavy atoms enhances its thermal stability. ACS Catal. 2016, 6, 3036-3046. [CrossRef]

30. Gotor-Fernández, V.; Busto, E.; Gotor, V. Candida antarctica lipase B: An ideal biocatalyst for the preparation of nitrogenated organic compounds. Adv. Synth. Catal. 2006, 348, 797-812. [CrossRef]

31. Kirk, O.; Christensen, M.W. Lipases from Candida antarctica: Unique biocatalysts from a unique origin. Org. Process Res. Dev. 2002, 6, 446-451. [CrossRef] 
32. Kobayashi, S. Lipase-catalyzed polyester synthesis-A green polymer chemistry. Proc. Jpn. Acad. Ser. B 2010, 86, 338-365. [CrossRef]

33. Numata, K.; Srivastava, R.K.; Finne-Wistrand, A.; Albertsson, A.-C.; Doi, Y.; Abe, H. Branched poly(lactide) synthesized by enzymatic polymerization: Effects of molecular branches and stereochemistry on enzymatic degradation and alkaline hydrolysis. Biomacromolecules 2007, 8, 3115-3125. [CrossRef] [PubMed]

34. Stavila, E.; Alberda van Ekenstein, G.O.; Woortman, A.J.; Loos, K. Lipase-catalyzed ring-opening copolymerization of epsilon-caprolactone and $\beta$-lactam. Biomacromolecules 2014, 15, 234-241. [CrossRef] [PubMed]

35. Stavila, E.; Loos, K. Synthesis of lactams using enzyme-catalyzed aminolysis. Tetrahedron Lett. 2013, 54, 370-372. [CrossRef]

36. Cheng, H.N.; Gu, Q.M.; Maslanka, W.W. Enzyme-catalyzed polyamides and compositions and processes of preparing and using the same. US Patents US 6677427 B1, 13 January 2004.

37. Numata, K.; Sato, R.; Yazawa, K.; Hikima, T.; Masunaga, H. Crystal structure and physical properties of Antheraea yamamai silk fibers: Long poly(alanine) sequences are partially in the crystalline region. Polymer 2015, 77, 87-94. [CrossRef]

38. Viswanathan, K.; Omorebokhae, R.; Li, G.; Gross, R.A. Protease-catalyzed oligomerization of hydrophobic amino acid ethyl esters in homogeneous reaction media using L-phenylalanine as a model system. Biomacromolecules 2010, 11, 2152-2160. [CrossRef] [PubMed]

39. Huang, Y.-B.; Cai, Y.; Yang, S.; Wang, H.; Hou, R.-Z.; Xu, L.; Xiao-Xia, W.; Zhang, X.-Z. Synthesis of tetrapeptide Bz-RGDS-NH 2 by a combination of chemical and enzymatic methods. J. Biotechnol. 2006, 125, 311-318. [CrossRef] [PubMed]

40. Sanda, F.; Fujiyama, T.; Endo, T. Chemical synthesis of poly- $\gamma$-glutamic acid by polycondensation of $\gamma$-glutamic acid dimer: Synthesis and reaction of poly- $\gamma$-glutamic acid methyl ester. J. Polym. Sci. A Polym. Chem. 2001, 39, 732-741. [CrossRef]

41. Uyama, H.; Fukuoka, T.; Komatsu, I.; Watanabe, T.; Kobayashi, S. Protease-catalyzed regioselective polymerization and copolymerization of glutamic acid diethyl ester. Biomacromolecules 2002, 3, 318-323. [CrossRef] [PubMed]

42. Bajorath, J.; Hinrichs, W.; Saenger, W. The enzymatic activity of proteinase K is controlled by calcium. Eur. J. Biochem. 1988, 176, 441-447. [CrossRef] [PubMed]

43. Berti, P.J.; Faerman, C.H.; Storer, A.C. Cooperativity of papain-substrate interaction energies in the S2 to S2' subsites. Biochemistry 1991, 30, 1394-1402. [CrossRef] [PubMed]

44. Armstrong, V.C.; Moodie, R.B. Protonation equilibria of amides and related compounds. Part II. Butyramide, n-butyrylglycine, and some carbamic acid esters. J. Chem. Soc. B 1968, 275-277. [CrossRef]

(C) 2016 by the authors; licensee MDPI, Basel, Switzerland. This article is an open access article distributed under the terms and conditions of the Creative Commons Attribution (CC-BY) license (http://creativecommons.org/licenses/by/4.0/). 